\title{
Laundry in a washing machine as a mediator of secondary and tertiary DNA transfer
}

Lev Voskoboinik, 1

Merav Amiel, 1

Ayeleth Reshef, 1

Ron Gafny, 1

Mark Barash, 2曰,3

Email mark.barash@uts.edu.au

1 DNA and Forensic Biology Laboratory, Division of Identification and Forensic Science, Israel Police, National HQ, Jerusalem, Israel AQ1

2 Faculty of Health Sciences and Medicine, Bond University, QLD, Gold Coast, 4223 Australia

3 Centre for Forensic Science, University of Technology

Sydney, Broadway, Ultimo, NSW, 2007 Australia

\section{Abstract}

The aim of this work was to investigate the possibility of secondary and tertiary DNA transfer during laundry. The modes of transfer tested were mixed and separate laundry of worn and unworn garments in household and public washing machines. In addition, the possibility of a background DNA carry-over from a washing machine's drum was investigated. In the mixed (worn and unworn garments washed together) laundry experiment, 22\% of samples from new unworn socks with no traceable DNA prior to experiment produced DNA profiles post-laundry. In the tertiary DNA transfer experiment performed in a public washing machine (unworn garments only), no detectable DNA profiles were observed. Samples collected from the internal drum of 25 washing and drying machines did not produce detectable STR profiles. The implications of these results are 
discussed in the context of forensic DNA casework analysis.

AQ2

AQ3

\section{Graphical Abstract}

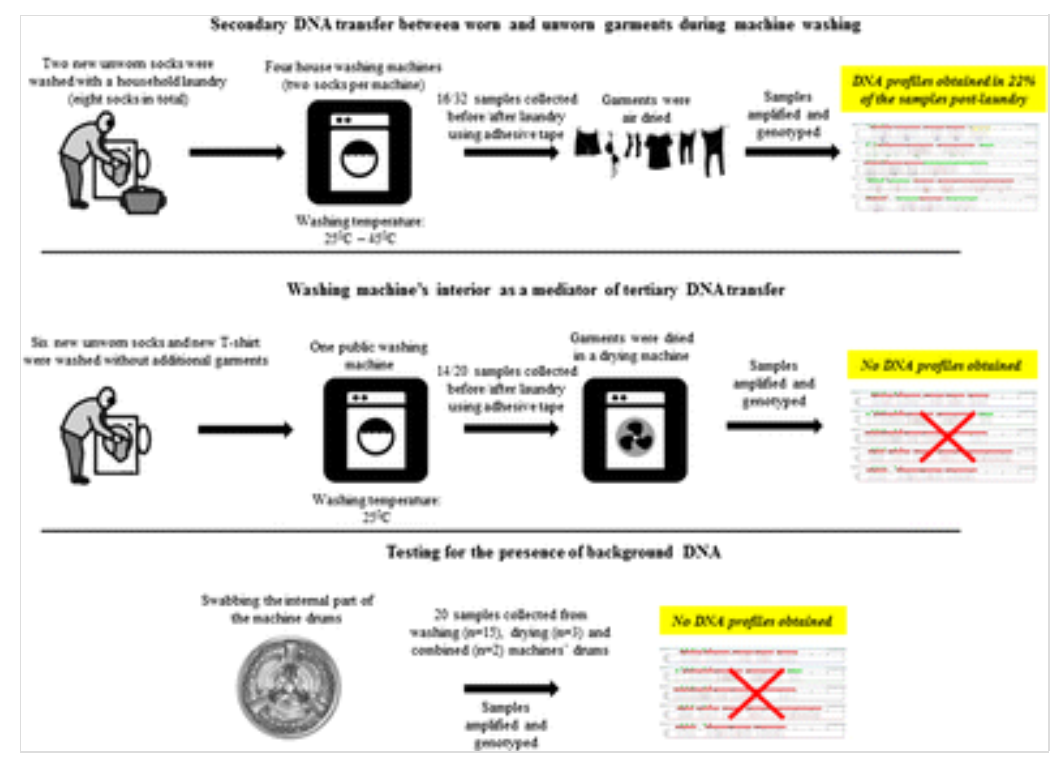

\section{Keywords}

Forensic science

Forensic DNA analysis

Secondary DNA transfer

Tertiary DNA transfer

STR analysis

Laundry

\section{Electronic supplementary material}

The online version of this article (doi: 10.1007/s00414-017-1617-3 ) contains supplementary material, which is available to authorized users.

\section{Introduction}

\section{AQ4}

In forensic cases, DNA is commonly left by an individual on objects at the crime scene either through direct contact or by spatter of body fluids. The presence of an individuals' DNA on a case item is usually considered as a 
strong evidence for his/her presence at the crime scene. Yet, DNA can be transferred to objects via a mediator, alive or inanimate. This process is known as indirect transfer $[1,2,3,4,5]$.

The possibility of secondary transfer of biological material is a major concern in forensic DNA interpretation. With continuously increasing sensitivity of commercially available STR kits, better PCR performance of inhibited samples, along with numerous improvements in collection, extraction and amplification methods, minute amounts of DNA, down to just tens of picograms, are sufficient to obtain a comparable DNA profile (reviewed by van Oorschot et al.) [6]. Increased sensitivity makes the probability of detecting a profile from secondary transfer DNA source more likely to occur. This mode of transfer becomes more problematic in cases in which DNA evidence is the major or sole incriminating evidence.

In a recent study, both laundry by hand and washing machine were examined as mechanisms for secondary transfer of DNA from epithelial and blood sources [6]. The results of these experiments indicated that obtaining a DNA profile from secondary transfer of epithelial cells via machine laundry is very unlikely. On the other hand, laundry of blood stained cloths with clean cloths resulted in substantial DNA transfer and full DNA profiles were obtained from both cloths. Another study demonstrated the possibility of DNA transfer via laundry for sperm stains as well [7].

In order to better understand and evaluate the prevalence of secondary DNA transfer via laundry, we decided to test scenarios which seem likely to occur on an everyday basis and can indeed account for DNA found on common case items. Two mechanisms of transfer via laundry were examined: one is the direct transfer of DNA between garments during mutual laundry (secondary transfer), and the second is the transfer of DNA left in a washing machine interior from previous washing cycles to newly washed garments (tertiary transfer). The later was examined in two experiments, laundry of clean garments in an empty washing machine and swabbing of the drums of washing and drying machines.

\section{Methods}

\section{Set up of transfer conditions}

Secondary DNA transfer between worn and unworn garments during machine washing 
Eight new unworn socks of various cotton blends (the exact content of each blend was not disclosed by the manufacturer) were subjected to laundry together with typical laundry content of four different households under various washing conditions (see Table 1 for details). Two socks, a thin one and a thick one, were washed under each set of conditions (Table 1).

\section{Table 1}

A summary of the home washing machine experiment. New unworn socks of a cotton ble were subjected to laundry together with a number of garments such as shirts, socks, a underwear, representing typical household laundry content

\begin{tabular}{|c|c|c|c|c|c|}
\hline \multirow{2}{*}{$\begin{array}{c}\text { Trial } \\
\text { number }\end{array}$} & \multirow{2}{*}{$\begin{array}{l}\text { Washing } \\
\text { machine } \\
\text { brand }\end{array}$} & \multirow{2}{*}{$\begin{array}{l}\text { Washing } \\
\text { temperature }\end{array}$} & \multirow{2}{*}{$\begin{array}{c}\text { Washing } \\
\text { powder brand } \\
\text { (local } \\
\text { manufacturers) }\end{array}$} & \multicolumn{2}{|c|}{$\begin{array}{c}\text { Number of samples with } \\
\text { DNA profiles/(number of } \\
\text { tested samples) }\end{array}$} \\
\hline & & & & $\begin{array}{l}\text { Prior to } \\
\text { laundry }\end{array}$ & Post-laundr \\
\hline 1 & $\begin{array}{l}\text { Lady } \\
\text { Crystal }\end{array}$ & $45^{\circ} \mathrm{C}$ & Sano Maxima & $0 /(4)$ & $1 /(8)$ \\
\hline 2 & $\begin{array}{l}\text { AEG } \\
\text { Lavamat } \\
45100 \\
\text { Electrolux }\end{array}$ & $40^{\circ} \mathrm{C}$ & Persil & $0 /(4)$ & $0 /(8)$ \\
\hline 3 & Constructa & $25^{\circ} \mathrm{C}$ & Ariel & $0 /(4)$ & $2 /(8)$ \\
\hline 4 & Whirlpool & $30^{\circ} \mathrm{C}$ & Sod & $0 /(4)$ & $4 /(8)$ \\
\hline Total & & & & $\begin{array}{l}0 \% \\
\text { please } \\
\text { move this } \\
\text { "0\%" down } \\
\text { the line } \\
(0 / 16=0 \%) \\
0 /(16)=\end{array}$ & $7(32)=22 \%$ \\
\hline
\end{tabular}

All the experiments were performed in the same manner and followed standard forensic protocols. The unworn garments were placed directly into the washing machine and washed together with the household laundry load. All the garments were handled with disposable gloves. The socks were turned inside out prior to laundry. After laundry, the socks were air dried. A total of eight socks were tested in this experiment.

Tertiary DNA transfer from previous washing cycles via washing machine's interior to clean garments 
Six new unworn socks and a T-shirt were subjected to laundry without additional items. Four socks and the T-shirt were of various cotton blends, while another two socks was of a wool blend (the exact content of each blend was not disclosed by the manufacturer). The laundry wash was performed in a frequently used public washing machine ("Maytron" brand), at approximately $25{ }^{\circ} \mathrm{C}$, using a local washing powder brand "OMO". Following the laundry, clothes were dried out using a public tumble dryer ("Maytag" brand) at light cycling conditions for approximately $40 \mathrm{~min}$.

\section{DNA presence in washing and drying machines}

To test the possibility of DNA transfer from a previous washing cycle that might remain on a washing or drying machine's interior, the drum of 15 washing machines from various households, three drying machines (including one public machine), and two combined washing and drying machines, both from a public place (see Supplemental Table 1 for details), were swabbed using a double-swabbing method, as previously described [8].

\section{Collection of biological material This heading should be leveled down by 1 .}

Aqree. Although not sure how to correct this online. Could you please change the font?

\section{Thanks}

All garments were sampled using three-layer adhesive tapes (Industrial Self Adhesives Limited, Nottingham, UK) as previously described [9]. In the secondary DNA transfer experiment, each of the eight socks was sampled prior to the washing process at two areas: internal ankle area and external toe area. Post-laundry, each sock was sampled at four areas: the two areas sampled before laundry as well as internal toes area and internal heel. Altogether, 16 samples were collected before laundry and 32 samples after laundry. Sterile gloves were used to handle all the garments during the experiment and were changed between handling each item. The reference samples of the household members were collected for comparison.

In the tertiary DNA transfer experiment, each of the six socks was sampled prior to the laundry process at two areas: internal heel area and internal toe area. The T-shirt was sampled in the left and right underarm seams.

Post-laundry, each sock was sampled at three areas: the two areas sampled before laundry as well as internal ankle area. The T-shirt was sampled in the 
same two areas as prior to laundry. Altogether, 14 samples were collected prior to laundry and 20 samples after. Sterile gloves were used to handle all the garments during the experiment and changed between handling each item. The internal drums of washing and drying machines were swabbed using a moist and a dry swab technique. Both swabs were combined in one $1.5-\mathrm{ml}$ tube and extracted together.

\section{DNA extraction, auantification. PCR amplification, and allele calling This heading should be leveled down by 1 .}

Aqree. Although not sure how to correct this online. Could you please change the font?

\section{Thanks}

DNA extraction, quantification and amplification were carried out in three different laboratories over an extensive time period, using the methods commonly applied in each lab for casework items.

DNA was extracted using one of the following methods:

1. Chelex extraction [8] and subsequent purification with DNA IQ kit (Promega), to a final volume of approximately $30 \mu \mathrm{l}$, for the secondary transfer trials.

2. Automatic extraction on the EZ1 robot (Qiagene), loaded with tissue extraction card in a final volume of $100 \mu 1$ and subsequent concentration using Savant speed-vac centrifuge (Thermo Scientific) down to a final volume of approximately $30 \mu \mathrm{l}$, for the tertiary transfer experiment.

3. Chelex extraction and subsequent concentration using the Microcon DNA Fast Flow filters down to a final volume of approximately $30 \mu \mathrm{l}$, for the DNA background presence in washing machine drums.

DNA yields in the secondary transfer trials were estimated using the Real Time PCR QuantifilerTM Human DNA Quantification Kit and the ABI PRISM ${ }^{\circledR} 7500$ Real Time PCR instrument (Thermo Fisher Scientific, Carlsbad, CA, US). Approximately 0.9 ng of DNA was amplified using the AmpFISTR ${ }^{\circledR} S G M$ Plus $^{\mathrm{TM}}$ kit following manufacturer recommendations. The minimum amount of DNA taken for amplification was set at $0.5 \mathrm{ng}$, according 
to routine laboratory protocols.

DNA yields in the tertiary transfer experiments were estimated using Real Time PCR EvaGreen SensiMix kit (Bioline, Alexandria, NSW) and Corbett Rotor-Gene 3000 (Qiagene, Doncaster, VIC, AU). All the samples, including with no detectable DNA quantity were subjected to amplification. The maximum template volume taken for amplification was $12 \mu \mathrm{l}$ per reaction. Amplifications were carried out using the PowerPlex ${ }^{\mathrm{TM}}$ ESI 16 kit (Promega Corp., Madison WI, US), according to the manufacturer recommendations.

DNA samples from the background DNA presence experiment were quantified using the Real Time PCR Quantifiler Trio ${ }^{\text {TM }}$ DNA Quantification Kit and the Quantstudio 6 digital PCR instrument, following manufacturer recommendations (Thermo Fisher Scientific, Carlsbad, CA, USA). All the samples, including samples with no detectable DNA were subjected to amplification. Amplifications were carried out using the GlobalFiler ${ }^{\mathrm{TM}}$ amplification kit according to the manufacturer recommendations (Thermo Fisher Scientific, Carlsbad, CA, US). The maximum template volume taken for amplification was $12 \mu \mathrm{l}$ per reaction.

Amplified PCR products were separated by electrophoresis on either an ABI PRISM® 3100, 3130XL or 3500XL Genetic Analyzers (Thermo Fisher Scientific, Carslbad, CA, US) using a 36-cm capillary, loaded with POP-4 polymer. The electrophoresis conditions for all the experiments were as follows: $5 \mathrm{~s}$ injection time, 30 min running time and $60{ }^{\circ} \mathrm{C}$ running temperature. Allele calls were designated using the Genemapper ${ }^{\circledR} 3.2$ software (Applied Biosystems, Carslbad, CA, US). The detection threshold for allele calling was set at 60 RFU and the stochastic threshold for the designation of homozygotes was set at $200 \mathrm{RFU}$, according to routine laboratory protocols.

\section{Results}

\section{Secondary DNA transfer}

No detectable DNA was identified in any of the 16 samples that were collected prior to laundry. Out of the 32 samples that were collected post-laundry, seven (22\%) contained DNA concentration above the minimal threshold of $0.06 \mathrm{ng} / \mu \mathrm{l}$ set for casework in our laboratory. Following amplification and electrophoresis, six out of the seven samples resulted in either a single-source STR profile or a mixture with a major contributor in all 
tested loci (Table 2). Four samples from washing machine number 4 resulted in the same single or major profile of a female member of the household. Of these, two samples showed additional low level alleles from a second contributor, which could be attributed to a male member of the household. All the low level alleles detected, correspond to homozygous alleles in this male's profile. One sample from washing machine number 3 resulted in a major profile matching a female member of the household. Another sample demonstrated a mixture of at least three contributors with a major component being a mixture of two male members of the household (grandfather and grandson). The only profile obtained from washing machine number 1 was a single source profile matching a female member of the household (Fig. 1).

Table 2

Summary of the genotyping results of the seven samples that were amplified post-laundry

\begin{tabular}{|l|l|l|l|l|}
\hline \multirow{2}{*}{ Trial number } & \multirow{2}{*}{ Sock type } & \multicolumn{1}{|c|}{ Area } & \multicolumn{2}{|c|}{ Mrofile } \\
\hline 1 & Thin & Internal heel & Female & \multicolumn{1}{|c|}{ Minor } \\
\hline 3 & Thin & External toes & Mixture of 2 males & 10 alleles \\
\hline 3 & Thick & External toes & Female & 1 allele \\
\hline 4 & Thin & Internal toes & Female & - \\
\hline 4 & Thin & Internal heel & Female & 1 allele \\
\hline 4 & Thin & Internal upper area & Female & 2 alleles \\
\hline 4 & Thick & Internal upper area & Female & - \\
\hline
\end{tabular}

\section{Fig. 1}

A single DNA profile (AmpFlSTR ${ }^{\circledR}$ SGM Plus ${ }^{\mathrm{TM}}$ ) obtained from a new, unworn sock after laundry in a washing machine along with typical household laundry. The high-quality single profile indicates that secondary DNA transfer through laundry is indistinguishable from a direct DNA transfer 

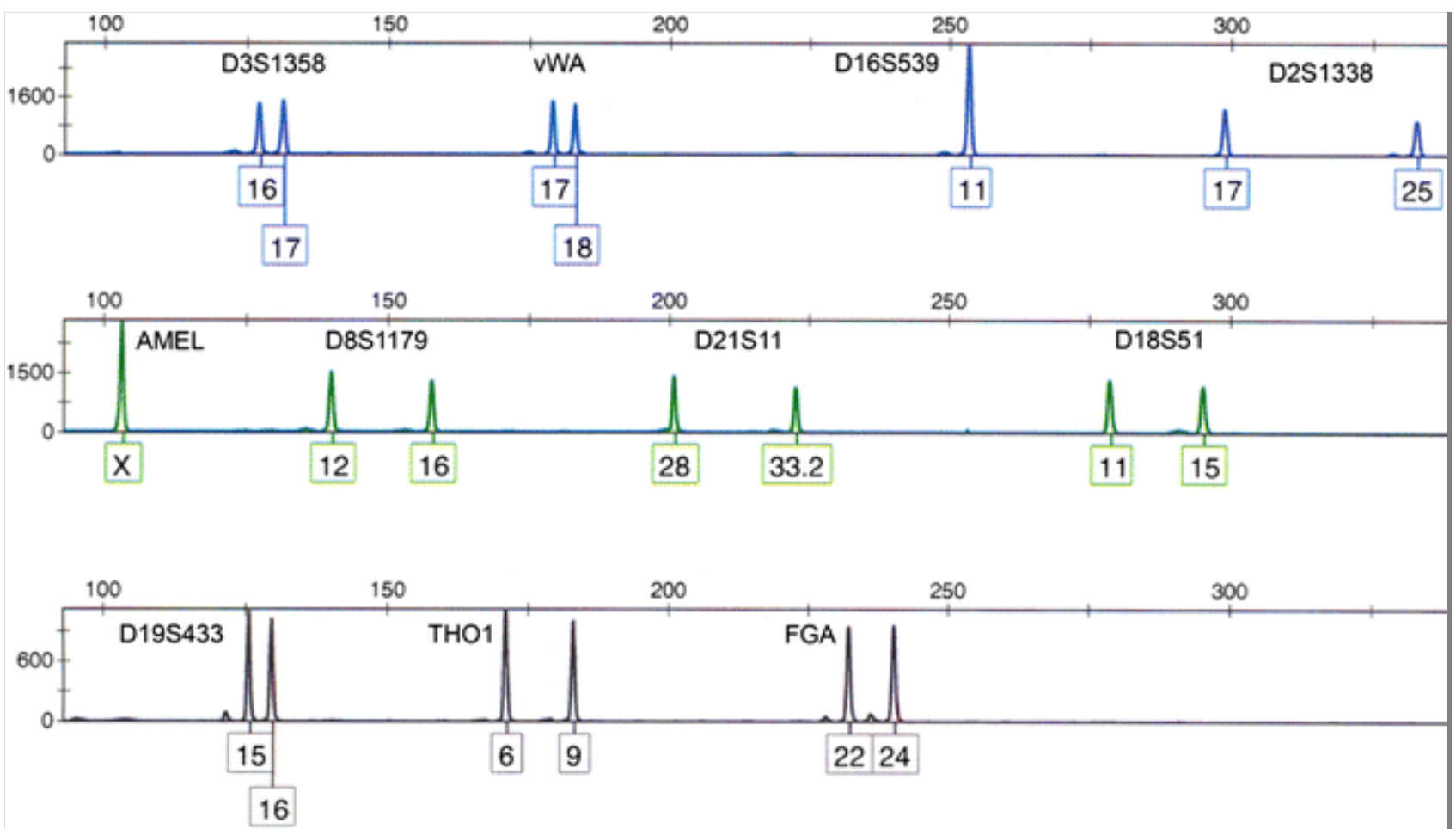

\section{Washing machine's interior as a mediator of DNA tertiary transfer}

No DNA was detected in any of the samples collected from the clothing articles (T-shirt and socks) prior to laundry. DNA quantitation of samples from the clothing articles taken after laundry in a public washing machine showed DNA quantity below the RT-PCR detection threshold (ranging between 0.001 and $0.003 \mathrm{ng} / \mu \mathrm{l})$.

Similarly, quantification of samples collected from washing machine drums showed no detectable DNA.

All the samples collected before and after the laundry as well as samples collected from washing machine drums were amplified and genotyped, as described in the "Methods" section. However, none of the samples produced detectable profiles.

\section{Discussion}

Advanced DNA profiling technologies allow obtaining more DNA profiles from trace amounts of biological material in a wide range of casework samples. Handling objects, touching surfaces, or wearing clothing may deposit sufficient amounts of epithelial cells or cell-free nucleic acids (CNAs), which can be successfully genotyped [10, 11, 12]. It has been evaluated that $30-50 \%$ of exhibits tested, provide a comparable profile 
originating from a trace DNA source [5]. Another study shows that up to $14.8 \mathrm{ng}$ of DNA may be recovered from a fabric which is held for $60 \mathrm{~s}$ and that approximately $22 \%$ of the tested population may represent "good shedders" [12]. It should be noted that the current use of the terms "good" and "bad" shedders is controversial and not yet in consensus in the forensic literature $[13,14,15]$.

The ability to easily obtain comparable DNA profiles from trace amounts of biological material raises the concern of acquiring an irrelevant DNA profile originating from secondary transfer. The probability to detect a secondary DNA transfer is increasing as more trace evidence samples are being tested. Forensic laboratories receive a continuously increasing number of case items that are worn, such as gloves and cloths; handled, such as guns, knives, and ropes; and items that are used to conceal objects such as socks. From our experience, socks are often used as gloves in burglary cases. The DNA obtained from such items frequently contains complex mixtures. It is important to appreciate whether the profiles obtained indicate a direct contact between the individuals and the tested object or could be a result of a secondary transfer.

In this set of experiments, we have tested the potential of laundry to mediate DNA transfer. There could be at least two possible mechanisms for DNA transfer through this mediator. One option is that different items in the laundry may transfer DNA from one onto the other, through shared washing (secondary transfer). A second, less probable possibility is that the washing machine retains biological material from previous washings and these are deposited onto a new load (tertiary transfer).

At first glance, it may seem surprising that laundry with bioactive ingredients does not degrade DNA. Apparently, the use of laundry detergents in a DNA extraction procedure has been previously described [16, 17, 18]. Considering that most of the laundry powders contain ingredients such as SDS, proteases, various chelating, and precipitating agents, they may actually assist in extracting clean, ready-to-amplify DNA molecules [19].

Previously, it has been shown that sperm cells have been transferred from one item to another during laundry [7, 20, 21, 22]. However, the possibility of shed epithelial cells transfer, sufficient for STR profiling, through laundry was shown to be unlikely [6]. In reality, a single laundry may contain many clothing articles from several individuals and contain various types of 
biological material. In this set of experiments, we wanted to test DNA transfer to clean garments under "real life" laundry conditions of several households.

We found that $22 \%$ of the tested samples from new unworn socks post-laundry contained enough DNA to obtain a full DNA profile. Growing sensitivity of the current amplification kits and especially of the next generation sequencing technology is expected to increase the percentage of post-laundry samples with enough DNA for obtaining a DNA profile. The majority of the obtained profiles in our experiments were mixtures, with one of the household members, usually a female, as a major contributor. This indicates that DNA does transfer readily from one item to another in a shared laundry environment, and that laundry process does not remove all the DNA from washed items. Therefore, DNA profile of an individual not in contact with the washed item can still be obtained from that item through secondary transfer in the washing machine. Yet, this mode of transfer limits the expected profiles on an item to a small group of individuals sharing mutual laundry.

As noted above, Kamphausen et al. showed the transfer of DNA from blood or saliva stains between garments in a washing machine is probable, while the transfer from epithelial cells is highly unlikely [6]. However, the authors note that the court of law is mainly interested in the probability of secondary DNA transfer from epithelial cell source. In our opinion, the main question is the probability of secondary transfer in a typical laundry while the differentiation to biological material types is of less relevance. The methodology of testing DNA transfer in laundry from epithelial cell used in the cited study was to rub one clean garment against the skin for a minute and then wash it with another clean garment. Under these conditions, the initial amount of DNA on the rubbed garment is likely to be very small and it is not surprising that after dilution during the laundry, no STR profiles could be observed on the second, clean garment. However, these conditions do not resemble a real-life laundry. Our results indicate that in typical household laundry, secondary transfer of DNA to clean garment was quite likely. The higher occurrence of secondary transfer DNA profiles in our experiment is probably due to the much higher initial DNA amount present in the laundry contents prior to the laundry.

In the shared laundry scenario, the profiles found on a garment are limited to a small group of individuals that wash clothes together in one washing machine. A more concerning scenario is the tertiary transfer of DNA in public washing machines from one user to another. Unlike the transfer in a mutual household laundry, under this scenario, completely unrelated individuals may appear on 
case items that neither they nor their relatives had any contact with. In the public washing machine experiment, we found that no detectable amounts of DNA were transferred from the washing machine onto new garments that were washed alone. Swabbing of the washing and drying machines' drums also did not reveal any detectable DNA profiles.

DNA profiles obtained on case items may serve as strong evidence for a contact between an individual and the item. In some cases, this information may serve as sole or major incriminating evidence.

A profile originating from secondary transfer may be uploaded to a DNA database, and may result in a cold hit. In some cases, especially in old cases, the cold hit that serves as a lead is not accompanied by more incriminating evidence, either because rigorous investigation is not followed or because passing of time restricts collection of additional evidence. Thus, an innocent might become a suspect in a criminal case. The forensic community acknowledges the possibility of secondary transfer as has previously been described in different studies [1, 2, 3, 4]. Yet, a forensic scientist testing a specific item has limited means to evaluate the probability of secondary transfer contribution to the obtained profile. The judge or jury is then confronted with a seemingly convincing piece of evidence, while this information may be misleading and cause severe injustice.

We recommend that DNA profiles obtained from case items as mentioned above should be evaluated with great caution. Such profiles can serve as investigative leads and circumstantial evidence, but should not serve as sole evidence for incrimination in court. This warning applies even more so to cold hits.

\section{Conclusion}

In forensic DNA casework, the presence of an individual's DNA on clothing item may be the result of secondary transfer. One mechanism for such transfer is mutual laundry of the (to be) case item with garments that another individual wore. In other words, a DNA profile from an unrelated person ' $\mathrm{X}$ ' could be detected on a garment with which he/she had no contact with, due to innocent DNA transfer. Our results demonstrate that this scenario is quite possible (22\% of samples) and may in fact result in high-quality DNA profiles. It should be noted that this study has investigated only the scenario when a new unworn sock is washed with other worn garments. A laundry of 
the worn garments may show different results, likely more mixtures. Nevertheless, these results highlight the importance of interpretation of DNA evidence in the context of the case item type and specific case circumstances. The forensic DNA community and especially the law enforcement authorities should always keep in mind that detecting someone's DNA profile on a clothing item or a touched object does not necessarily link this person to the crime scene.

On the other hand, results of our tertiary transfer experiments indicate that the possibility of DNA transfer between separate washing cycles via the deposition of biological material in a washing or drying machine's drum is unlikely. This finding is particularly important as no empirical data on this question has been previously available. It should be noted though that continuing improvement of the forensic DNA typing technology may increase the chances for DNA recovery in this type of scenario.

\section{Electronic supplementary material}

\section{Supplemental Table 1}

(DOCX $20 \mathrm{~kb})$

\section{References}

1. Goray M, Eken E, Mitchell RJ, van Oorschot RA (2010) Secondary DNA transfer of biological substances under varying test conditions.

Forensic Sci Int Genet 4:62-67. doi: 10.1016/j.fsigen.2009.05.001

2. Goray M, Mitchell RJ, van Oorschot RA (2010) Investigation of secondary DNA transfer of skin cells under controlled test conditions. Leg Med 12:117-120. doi: 10.1016/j.legalmed.2010.01.003

3. Ladd C, Adamowicz MS, Bourke MT, Scherczinger CA, Lee HC (1999) A systematic analysis of secondary DNA transfer. J Forensic Sci 44:1270-1272. doi: 10.1520/JFS14599J

4. Lowe A, Murray C, Whitaker J, Tully G, Gill P (2002) The propensity of individuals to deposit DNA and secondary transfer of low level DNA from individuals to inert surfaces. Forensic Sci Int 129:25-34. doi: 
5. Wickenheiser RA (2002) Trace DNA: a review, discussion of theory, and application of the transfer of trace quantities of DNA through skin contact. J Forensic Sci 47:442-450

6. Kamphausen T, Fandel SB, Gutmann JS, Bajanowski T, Poetsch M (2015) Everything clean? Transfer of DNA traces between textiles in the washtub. Int J Legal med 129:709-714. doi: 10.1007/s00414-015-1203-5

7. Brayley-Morris H, Sorrell A, Revoir AP, Meakin GE, Court DS, Morgan RM (2015) Persistence of DNA from laundered semen stains: implications for child sex trafficking cases. Forensic Sci Int Genet 19:165-171. doi: 10.1016/j.fsigen.2015.07.016

8. Walsh PS, Metzger DA, Higuchi R (1991) Chelex-100 as a medium for simple extraction of DNA for Pcr-based typing from forensic material. BioTechniques 10:506-513. doi: 10.2144/000114018

9. Barash M, Reshef A, Brauner P (2010) The use of adhesive tape for recovery of DNA from crime scene items. J Forensic Sci 55:1058-1064. doi: $10.1111 /$ j.1556-4029.2010.01416.x

10. Kita T, Yamaguchi H, Yokoyama M, Tanaka T, Tanaka N (2008) Morphological study of fragmented DNA on touched objects. Forensic Sci Int Genet 3:32-36. doi: 10.1016/j.fsigen.2008.09.002

11. Quinones I, Daniel B (2012) Cell free DNA as a component of forensic evidence recovered from touched surfaces. Forensic Sci Int Genet 6:26-30. doi: 10.1016/j.fsigen.2011.01.004

12. Daly DJ, Murphy C, McDermott SD (2012) The transfer of touch DNA from hands to glass, fabric and wood. Forensic Sci Int Genet 6:41-46. doi: 10.1016/j.fsigen.2010.12.016

13. Meakin G, Jamieson A (2013) DNA transfer: review and implications for casework. Forensic Sci Int Genet 7:434-443. doi:

$10.1016 /$ j.fsigen.2013.03.013

14. Goray M, Fowler S, Szkuta B, van Oorschot RA (2016) Shedder 
status - an analysis of self and non-self DNA in multiple handprints deposited by the same individuals over time. Forensic Sci Int Genet 23:190-196. doi: 10.1016/j.fsigen.2016.05.005

15. Kamphausen T, Schadendorf D, von Wurmb-Schwark N, Bajanowski T, Poetsch M (2012) Good shedder or bad shedder - the influence of skin diseases on forensic DNA analysis from epithelial abrasions. Int J Legal Med 126:179-183. doi: 10.1007/s00414-011-0579-0

16. Bahl A, Pfenninger M (1996) A rapid method of DNA isolation using laundry detergent. Nucleic Acids Res 24:1587-1588. doi: 10.1093/nar /24.8.1587

17. Nasiri H, Forouzandeh M, Rasaee MJ, Rahbarizadeh F (2005) Modified salting-out method: high-yield, high-quality genomic DNA extraction from whole blood using laundry detergent. J Clin Lab Anal 19:229-232. doi: 10.1002/jcla.20083

18. Pusch C (1997) A simple and fast procedure for high quality DNA isolation from gels using laundry detergent and inverted columns. Electrophoresis 18:1103-1104. doi: 10.1002/elps.1150180713

19. Bajpai D, Tyagi VK (2007) Laundry detergents: an overview. J Oleo Sci 56:327-340

20. Farmen RK, Cortez P, Frøyland ES (2008) Spermatozoa recovered on laundered clothing. Forensic Sci Int Genet Suppl Ser 1:418-420. doi: 10.1016/j.fsigss.2007.10.218

21. Jobin RM, De Gouffe M (2003) The persistence of seminal constituents on panties after laundering. Significance to investigations of sexual assault. J Can Soc Forensic Sci 36:1-10. doi:

10.1080/00085030.2003.10757551

22. Kafarowski E, Lyon A, Sloan M (1996) The retention and transfer of spermatozoa in clothing by machine washing. J Can Soc Forensic Sci 29:7-12. doi: 10.1080/00085030.1996.10757042 